\title{
Manajemen Anestesi pada Penderita Sindroma Pfeiffer dengan Posisi Sphinx
}

\author{
Radian Ahmad Halimi, Dewi Yulianti Bisri, Tatang Bisri \\ Departemen Anestesiologi dan Terapi Intensif Fakultas Kedokteran Universitas Padjadjaran RS. Dr. Hasan Sadikin \\ Bandung
}

\begin{abstract}
Abstrak
Sindroma pfeiffer adalah kelainan genetik autosomal dominan berupa fusi prematur tulang kepala dan tubuh lainnya. Operasi rekonstruksi kraniofasial pada pasien dengan sindrom pfeiffer memberikan tantangan tersendiri bagi ahli anestesi. Pada laporan kasus ini, seorang anak perempuan berusia 18 bulan datang ke rumah sakit Hasan Sadikin Bandung dengan keluhan kelainan bentuk kepala sejak lahir. Kelainan tersebut disertai dengan proptosis mata, hipoplasia maksila bilateral, high arc palate, hipotelorisme dan hidrosefalus, namun tidak terdapat riwayat obstruksi jalan nafas. Pasien direncanakan dilakukan prosedur rekonstruksi kraniofasial dan tarsorhaphy dengan posisi modifikasi prone (posisi sphinx). Permasalahan yang terjadi selama operasi adalah obstruksi vena juguler, perdarahan dan kebocoran cairan serebrospinal pascaoperasi. Operasi berlangsung selama 19 jam. Pascaoperasi pasien dirawat di PICU dan dipindahkan ke ruangan perawatan biasa pada hari ke 4 . Penanganan perioperatif pasien dengan sindroma pfeiffer yang akan menjalani prosedur operasi kraniofasial membutuhkan penanganan secara multidisiplin dan dibutuhkan pemahaman yang mendalam mengenai fisiologi, potensi permasalahan intraoperasi, resiko dan komplikasi pascaoperasi untuk mencapai hasil luaran yang baik.
\end{abstract}

Kata kunci: Posisi sphinx, rekonstruksi kraniofasial, sindroma pfeiffer

JNI 2018;7(3): 157-63

\section{Anesthesia Management in Patients with Pfeiffer Syndrome with Sphinx Position}

\begin{abstract}
Pfeiffer syndrome is a dominant autosomal genetic disorder characterized by premature fusion of head and other body bones. Craniofacial reconstruction surgery in patients with Pfeiffer syndrome presents a challenge for an anaesthesiologist. This case report discusses about 18 month old girl came to the Hasan Sadikin hospital in Bandung with complaints of clover head shape from birth. The other abnormalities consist of eye proptosis, bilateral maxilla hypophlasia, high arc palate, hypotelorism and hydrocephalus. There was no history of obstructive sleep apneau (OSA). The patient underwent craniofacial vault reconstruction procedure and a tarrsorhaphy with modified prone position (sphinx position). During the operation, there were problems occured such as jugular venous obstruction, bleeding and postoperative cerebrospinal fluid leakage. The procedure takes 19 hours long, and after the operation, the patient admitted to the PICU and being transferred to the ward on day-4. The perioperative treatment of patients undergoing craniofacial surgery requires a multidisciplinary treatment approach, and deep understanding of the physiology, potential intraoperative problems, risks and postoperative complications to achieve better outcomes.
\end{abstract}

Key words: Craniofacial reconstruction, pfeiffer syndrome, sphinx position 


\section{Pendahuluan}

Sindroma pfeiffer merupakan kelainan genetik autosomal dominan yang jarang terjadi, yang ditandai dengan fusi prematur tulang-tulang kepala (kraniosinostosis Pertumbuhan otak yang terbatas akibat fusi prematur tulang kepala dapat menyebabkan gangguan perkembangan dan masalah neurologis seperti hidrosefalus, bahkan beberapa penderita berumur pendek. Rekonstruksi kraniofasial pada pasien dengan sindroma pfeiffer memberikan tantangan tersendiri, baik bagi dokter bedah saraf maupun anestesi. Tujuan tindakan operasi adalah untuk memproteksi jalan nafas, memproteksi fungsi mata, dan manajemen peningkatan tekanan intrakranial (TIK). Usia yang tepat untuk dilakukannya tindakan operasi masih menjadi perdebatan hingga saat ini. ${ }^{1}$

Permasalahan anestesi pada pasien sindroma pfeiffer yang akan tindakan rekonstruksi kraniofasial meliputi masalah kesulitan penanganan jalan nafas, komplikasi akibat posisi operasi (posisi sphinx yang merupakan modifikasi posisi prone), kehilangan darah masif, pergeseran cairan yang hebat, shunt-dependent hydrocephalus dan waktu anestesi yang panjang, dan permasalahan pascaoperasi lainnya sehingga membutuhkan monitoring ketat. Permasalahan tersebut dapat diantisipasi dengan perencanaan secara multidisiplin dan persiapan perioperatif yang baik..$^{1-2}$

\section{Kasus}

\section{Anamnesis}

Seorang anak perempuan berusia 18 bulan dibawa ke Rumah Sakit Hasan Sadikin dengan keluhan kelainan bentuk kepala sejak lahir. Berdasarkan anamnesis didapatkan riwayat perkembangan ukuran kepala yang tidak membesar dengan cepat, terdapat kelainan tangan, mata tampak membesar, kemerahan, muncul bintik putih pada lensa mata dan mata tidak dapat menutup saat tidur. Pasien ini lahir melalui proses persalinan spontan pada usia kehamilan 38 minggu dengan berat badan lahir $2.7 \mathrm{~kg}$ dan segera menangis setelah dilahirkan. Riwayat penurunan kesadaran, muntah, kejang disangkal, tidak ada demam, batuk dan pilek.

\section{Pemeriksaan Fisik}

Kesadaran: compos mentis. Tinggi badan: 80 $\mathrm{cm}$, berat badan: $9 \mathrm{~kg}$, lingkar kepala: $48 \mathrm{~cm}$, laju nadi: $114 \mathrm{x} / \mathrm{m}$, frekuensi nafas: $28 \mathrm{x} /$ menit, suhu: $36,7^{\circ} \mathrm{C}, \mathrm{SpO}_{2}$ : 98-99\%. Kepala: bentuk dismorfik, cloverleaf, exoftalmus bilateral dengan keratitis bilateral, pupil bulat isokor, diameter 3 $\mathrm{mm}$ bilateral, refleks cahaya positif, hipoplasia maxilla bilateral, high arc palate, hipotelorisme, narrow bitemporal, leher: dalam batas normal, thoraks: bentuk dan gerak tidak simetris, paru: ronkhi -/-, wheezing-/-, jantung: S1=S2 murni reguler, murmur (-), abdomen: bising usus $(+)$ menurun, lembut, ekstremitas: broad thumb $(+)$, tonus otot meningkat pada 4 ekstremitas, refleks fisiologis: meningkat, refleks patologis: Chaddock $(+)$

\section{Pemeriksaan Penunjang}
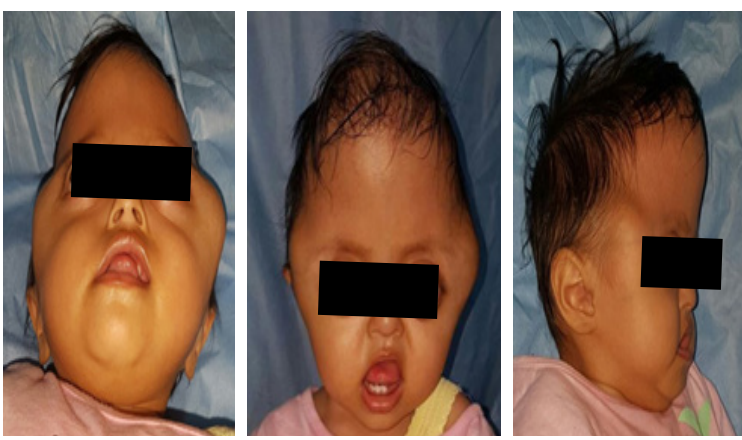

\section{Pemeriksaan Rontgen Thoraks}

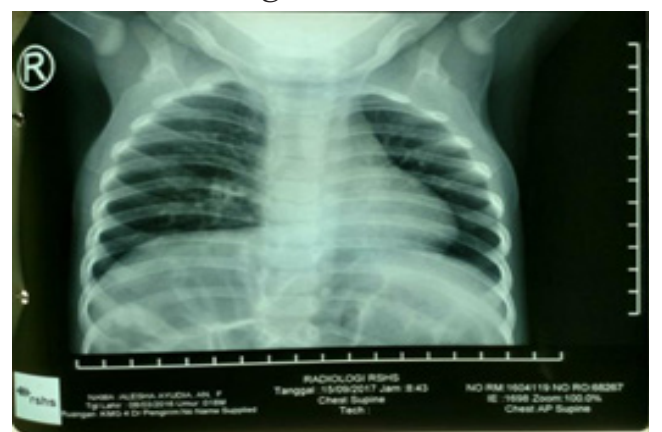

Hasil pemeriksaan rontgen thorax didapatkan cor pulmonal dalam batas normal

\section{Pemeriksaan CT-scan}

Pemeriksaan CT-scan menunjukkan bentuk calvaria dengan diameter vertical lebih besar dari horizontal sehingga menyerupai clover 
Pemeriksaan Laboratorium

\begin{tabular}{lllllll}
\hline $\mathrm{Hb}$ & $\mathrm{Ht}$ & Leukosit & Trombosit & PT & INR & APTT \\
\hline 11,5 & 36,9 & 10.460 & 362.000 & 10,3 & 0,94 & 28,6 \\
SGOT & SGPT & Ureum & Kreatinin & Albumin & Natrium & Kalium \\
36 & 15 & 25 & 0,28 & 3,8 & 143 & 4,5 \\
\hline
\end{tabular}

\section{Pemeriksaan CT scan}
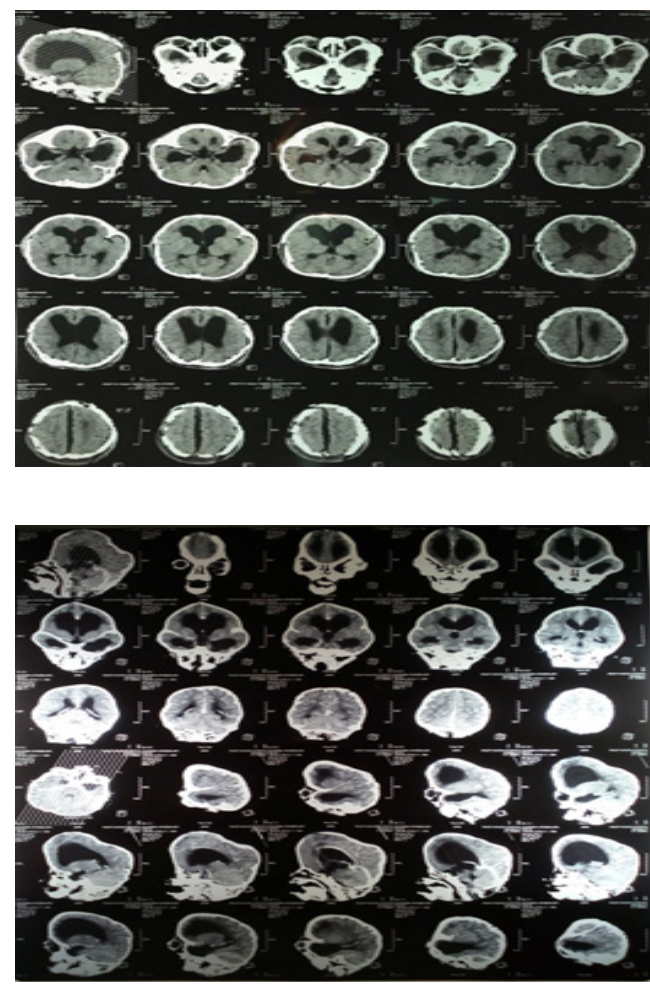

leaf, disertai sutura yang sudah menutup dan fontanela yang masih terbuka, hidrocephalus non communicans, spikula pada calvaria yang protruded dan proptosis bulbus oculi bilateral.

\section{Pembahasan}

Sindrom Pfeiffer pertama kali dikemukakan oleh Pfeiffer pada tahun 1964, dan saat itu dilaporkan sebanyak 60 kasus. Sindrom pfeiffer merupakan kelainan genetik autosomal dominan yang terjadi pada 1 per 100.000 individu kaukasia dan jarang terjadi pada ras asia. Sindrom pfeiffer ditandai dengan fusi prematur tulang-tulang kepala (craniosinostosis), tulang lengan, jari tangan dan jari kaki. ${ }^{1}$ Berdasarkan derajat keparahan fenotipnya, sindroma pfeiffer dibagi menjadi 3 subtipe klinis, yakni: Tipe 1 dikenal sebagai

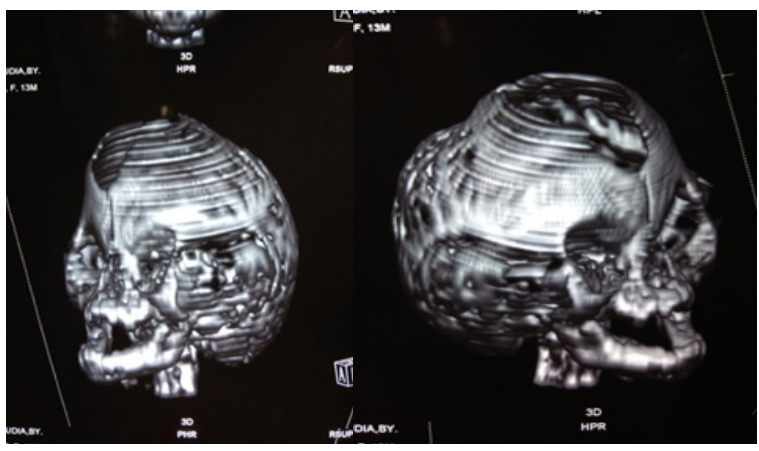

sindroma pfeiffer klasik yang ditandai dengan adanya kondisi brakhicephali, hipoplasia midface, dan abnormalitas jari tangan dan kaki. Penderita tipe 1 mempunyai tingkat intelegensia dan hasil luaran yang baik. Tipe 2 ditandai dengan adanya kelainan deformitas tulang tengkorak kepala yang cloverleaf, proptosis mata yang berat, abnormalitas jari tangan dan kaki, ankilosis atau sinostosis sikut tangan, adanya keterlambatan perkembangan dan komplikasi neurologis. Tengkorak cloverleaf dapat menyebabkan terjadinya gangguan pertumbuhan otak, dan proptosis berat dapat menyebabkan terjadinya gangguan penglihatan yang berat. Tipe 3 ditandai dengan kelainan yang hampir sama dengan tipe 2, namun tidak disertai adanya tengkorak kepala yang cloverleaf. Tipe 2 dan 3 biasanya menunjukkan hasil luaran yang buruk, karena memilki resiko kematian yang tinggi akibat gangguan neurologis berat (peningkatan TIK hingga terjadinya herniasi otak), dan gangguan pernafasan. $^{2}$

Berdasarkan kasus ini, pasien termasuk klasifikasi pfeiffer tipe 2 yang ditandai dengan bentuk kepala dismorfik, cloverleaf, proptosis mata bilateral dengan kondisi kedua mata keratitis, hipoplasia maxilla bilateral, high arc palate, hipotelorisme, dan narrow bitemporal, serta pada kedua ekstremitas terdapat kondisi broad thumb. 


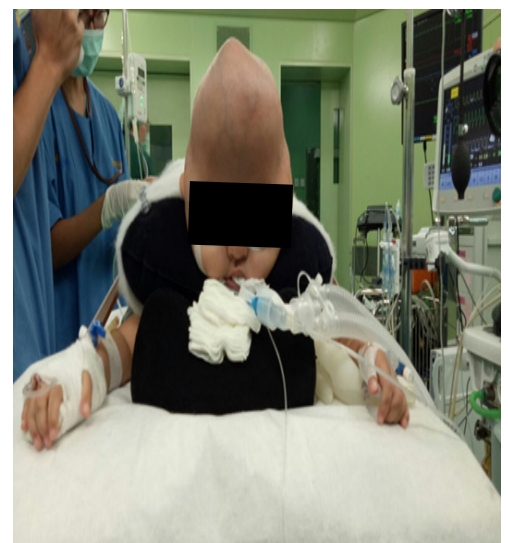

Gambar 3. Sniffing / Sphinx Position

\begin{tabular}{lrl}
\hline Input & & Output \\
\hline PRC: & $416 \mathrm{cc}$ & $\begin{array}{l}\text { Perdarahan: } \\
500 \mathrm{cc}\end{array}$ \\
& & $\begin{array}{l}\text { Produksi urine: } \\
\text { FFP: }\end{array} \quad 151 \mathrm{cc}$ \\
& & $800 \mathrm{cc}(19 \mathrm{jam})$ \\
$\mathrm{RL}:$ & $790 \mathrm{cc}$ & \\
$\mathrm{NaCl} 0,9 \%: 400 \mathrm{cc}$ & \\
\hline
\end{tabular}

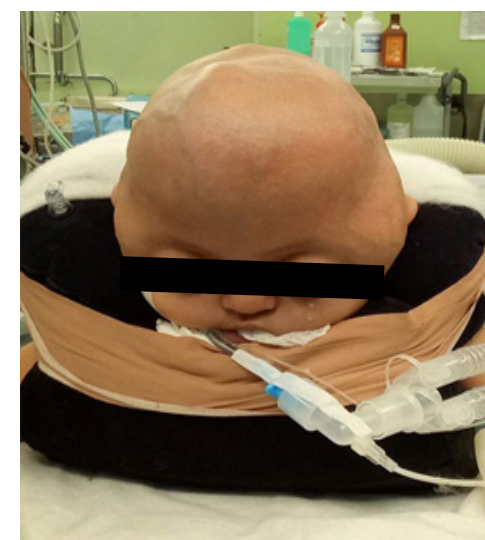

Gambar 4. Kondisi Venekstasi Vena

Pasien ini juga didapatkan kondisi hidrosephalus akibat perkembangan kranium yang terganggu. Walaupun penderita sindrom pfeiffer memiliki prognosis yang buruk, beberapa penelitian melaporkan hasil yang baik pada beberapa kasus yang mendapatkan intervensi medikal dan bedah yang dilakukan pada stadium awal. Secara umum prosedur operasi bukan hanya bertujuan estetik, namun untuk mengkoreksi bentuk tulang kepala dan dekompresif otak, memperpanjang tulang mata agar bola mata bisa masuk ke

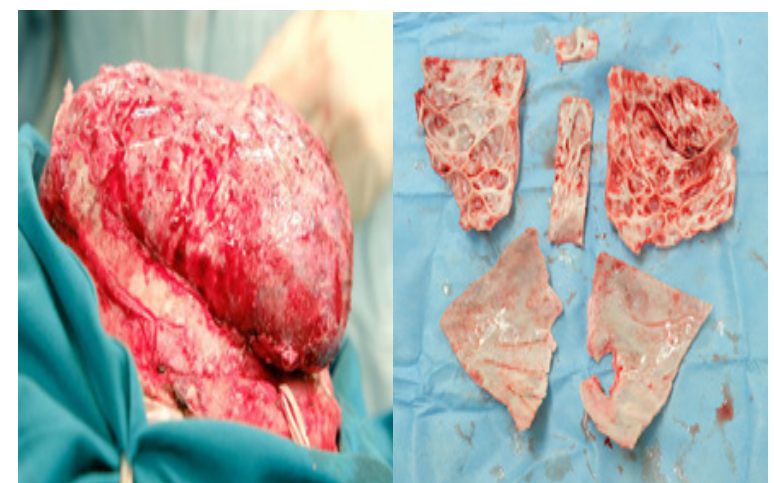

Gambar 5. Temuan Intraoperasi

dalam dan kelopak mata dapat menutup, dan membuka jalan nafas nasofaringeal dengan memperbaiki kompleks nasomaxila-zygomatica. Tindakan operasi pada usia dini dilakukan untuk mengoptimalkan perkembangan otak normal dan fungsi kognitif.,

Prosedur neurosurgikal dan kraniofasial selalu memberikan tantangan bagi anestesiologis. Anomali kraniofasial sulit untuk dikelola dari pandangan surgikal dan anestesi. Kraniosinostosis merupakan defek perkembangan yang ditandai fusi prematur satu atau lebih sendi tulang tengkorak yang menyebabkan deformitas dan restriksi perkembangan otak. Koreksi surgikal bertujuan untuk remodelling tulang tengkorak dengan teknik strip craniectomy, spring assisted cranioplasty, bilateral craniectomy dengan atau tanpa pendekatan frontoorbital dan posterior, dan remodelling dan rekonstruksi tulang tengkorak. Manajemen pediatrik neuroanestesi pasien ini dititikberatkan pada pemahaman terhadap perubahan fisiologi dan patofisiologi pada sekumpulan sindroma yang terjadi. ${ }^{3}$ Operasi koreksi kraniofasial ditentukan oleh pertimbangan yang berhubungan dengan proteksi jalan nafas, proteksi mata, dan manajemen tekanan tinggi intrakranial. Waktu operasi menjadi masalah yang penting. Operasi awal (3-6 bulan) memberikan keuntungan karena tulangnya masih lunak dimana remodelling lebih mudah. Semakin besar usia dilakukannya tindakan koreksi kraniofasial, semakin sulit kondisi tulang untuk dilakukan remodeling. ${ }^{3}$ Penanganan pasien ini dilakukan secara multidisiplin keilmuan yang terdiri dari dokter bedah syaraf sebagai 
ketua tim, dokter spesialis bedah plastik, dokter spesialis anak tumbuh kembang, ahli perinatologi dan ahli anestesi. Indikasi tindakan operasi pasien ini adalah untuk mencegah terjadinya peningkatan TIK lebih lanjut dengan melakukan dekompresif kranium, memproteksi mata dengan dilakukannya tindakan tarsorrhaphy serta mengoptimalkan perkembangan otak dengan dilakukannya rekonstruksi kranium. Kondisi hidrosefalus memberat 3 hari pascaoperasi dan dilakukan tindakan pemasangan $v p$-shunt. Berdasarkan kondisi tersebut maka sebaiknya tindakan pemasangan $v p$ shunt dilakukan pada saat tindakan operasi pertama dilakukan.

Evaluasi preoperasi dilakukan secara spesifik berdasarkan kondisi klinis yang dialami oleh pasien serta tindakan operasi yang akan dilakukan. Evaluasi jalan nafas dan fungsi jantung diperlukan untuk mengidentifikasi kebutuhan untuk dilakukannya tindakan intervensi spesifik sebelum dilakukannya tindakan operasi rekonstruksi kraniofasial. Evaluasi terhadap adanya kondisi hipertensi intrakranial juga diperlukan untuk menentukan teknik anestesi dan pemilihan obat-obatan yang tidak akan memperberat kondisi peningkatan TIK tersebut. Obstructive sleep apnea (OSA) dan komplikasi pernafasan telah dilaporkan pada beberapa kasus pasien dengan sindroma kraniofasial, evaluasi yang perlu dilakukan adalah dengan melakukan anamnesis pada orang tua pasien, serta dilakukan pemeriksaan saat pasien tidur oleh dokter bagian telinga hidung dan tenggorokan (THT). ${ }^{4}$ Pemeriksaan darah rutin, biokimia, dan faktor koagulasi perlu dilakukan, serta pemesanan produk darah dan faktor pembekuan, karena kemungkinan terjadinya perdarahan intraoperasi yang hebat intraoperasi. Orang tua pasien harus dilakukan inform consent mengenai resiko operasi baik resiko operasi dan anestesi, terutama mengenai masalah perdarahan dan kemungkinan dilakukannya transfusi darah yang masif serta kemungkinan terjadinya venous air embolism (VAE). ${ }^{4}$ Sebagian besar bayi tidak membutuhkan premedikasi, kecuali yang sudah mengalami kecemasan perpisahan dapat diberikan premedikasi midazolam per oral, namun penggunaannya harus dibatasi pada pasien yang mengalami obstructive sleep apnea dan peningkatan TIK sebelumnya. ${ }^{4}$ Induksi anestesi dapat menggunakan teknik inhalasi atau intravena, bergantung pada dokter anestesi, pasien, dan orang tua pasien, bergantung pada adanya potensi gangguan jalan nafas dan potensi sulitnya untuk pemasangan jalur intravena. Hipoplasia midface dapat berpotensi untuk sulitnya melakukan tindakan ventilasi dengan sungkup, sehingga perlu dipertimbangkan untuk mempersiapkan peralatan untuk menguasai jalan nafas yang lebih mutakhir. ${ }^{4}$ Berdasarkan literatur dijelaskan bahwa tipe pipa dan teknik pemasangan pipa endotrakheal yang digunakan bervariasi, bergantung pada prosedur operasi yang dilakukan. Namun berdasarkan literatur tersebut mengatakan bahwa intubasi nasal lebih dipilih untuk digunakan karena memberikan stabilitas yang baik pada semua jenis prosedur operasi walaupun dilakukan perubahan posisi selama operasi. Posisi pipa endotrakheal harus selalu dipastikan aman saat posisi kepala pasien fleksi dan ekstensi maksimal, hal tersebut dilakukan untuk mencegah terjadinya kejadian ekstubasi secara tidak sengaja atau masuknya pipa kedalam endobronkhial saat dilakukannya perubahan posisi pasien. ${ }^{4}$

Monitoring tanda vital perlu dilakukan dengan monitor nonivasif standar (Elektrokardiografi, $\mathrm{SpO}_{2}, \mathrm{EtCO}_{2}$, central venous catheter (CVC), temperatur), dan monitor invasif seperti arterial line. Dua kateter intravena yang berukuran besar dan CVC perlu dipasang untuk mengantisipasi terjadinya perdarahan yang hebat intraoperasi. Penggantian darah dan cairan perlu sangat diperhatikan pada prosedur ini, perlu dilakukan monitoring ketat untuk diatesis perdarahan, elektrolit, dan suhu tubuh pada pasien ini. Penghangat sangat diperlukan untuk menjaga suhu selama operasi berlangsung. ${ }^{4,5}$ Berdasarkan kasus ini tidak didapatkan riwayat obstructive sleep apnea, dan riwayat kelainan jantung bawaan, namun dicurigai adanya difficult airway sehingga tidak diberikan premedikasi dengan midazolam oral. Hasil pemeriksaan laboratorium dalam batas normal. Persiapan darah sudah tersedia sebelum pasien dibawa ke kamar operasi. Setelah dilakukan induksi anestesi dilakukan pemasangan 
infus dengan ukuran besar pada kaki, arterial line untuk monitoring tekanan darah dan pengambilan sampel darah, kateter vena sentral pada vena femoralis untuk mengantisipasi kehilangan darah masif, stetoskop prekordial, kapnografi, penghangat tubuh dan video laringoskopi untuk persiapan apabila terjadi kesulitan saat dilakukan intubasi endotrakheal.

Berdasarkan suatu literatur mengatakan bahwa pada tindakan operasi rekonstruksi kranial dengan teknik rekonstruksi total calvarial biasanya menggunakan posisi operasi modifikasi prone atau posisi sphinx, dimana pasien diposisikan prone namun dengan posisi kepala dan leher yang ekstensi. Prosedur ini merupakan suatu prosedur yang ekstensif dan memiliki beberapa resiko dan komplikasi operasi yang berat, sehingga pada beberapa pusat pendidikan kesehatan telah banyak ditinggalkan dan beralih pada operasi yang dilakukan pada beberapa tahapan dengan jarak beberapa bulan, namun dengan resiko yang lebih rendah. Komplikasi meliputi perdarahan masif dan emboli udara pada vena akibat posisi kepala yang lebih tinggi dibandingkan posisi jantung. Sphinx position juga dapat menyebabkan obstruksi aliran darah vena yang berakibat memperberatnya kondisi edema otak dan perdarahan. ${ }^{5}$

Posisi modifikasi prone (sea lion atau sphinx position) sebaiknya dihindari pada pasien dengan tulang servikal yang tidak stabil. Mata sebaiknya diberikan salep mata khusus secara berkala untuk mencegah terjadinya kondisi mata yang kering, karena biasanya pada pasien dengan proptosis biasanya tidak dapat menutup mata secara sempurna, selain itu daerah mata merupakan daerah operasi (dilakukan tindakan tarsorrhaphy). Daerah yang mengalami penekanan harus dilindungi dan diberikan ganjalan untuk menghindari cedera akibat tekanan. ${ }^{6}$ Teknik operasi pada kasus ini menggunakan teknik rekonstruksi total calvarial. Teknik tersebut dipilih berdasarkan aspek biaya operasi yang lebih murah karena tindakan operasi yang dilakukan lebih sedikit walaupun memiliki resiko dan komplikasi operasi yang lebih berat. Pada kasus ini setelah dilakukan posisi sphinx dengan kepala ekstensi terjadi venektasi vena kepala yang menandakan terjadinya obstruksi vena jugularis sehingga drainase pembuluh darah otak dan kepala terganggu, sehingga dilakukan reposisi ulang terhadap posisi kepala. Studi literatur menyatakan bahwa seluruh anak yang dilakukan prosedur kraniotomi sebaiknya dilakukan perawatan pascaoperasi di ruang ICU. Ekstubasi umumnya dilakukan di kamar operasi. Pasien yang tidak di ekstubasi dan dilakukan ventilasi mekanik di PICU adalah pasien dengan posisi prone dan durasi operasi yang panjang, dengan pembengkakan daerah wajah yang signifikan dan adanya gejala OSA preoperasi terutama saat tidur. Kondisi anomali trakhea telah dilaporkan pada beberapa kasus, dan sebaiknya disarankan untuk dilakukan tindakan bronkhoskopi untuk mengevaluasi adanya kemungkinan anomali pada jalan nafas. Kondisi lain yang perlu diperhatikan pascaoperasi adalah adanya kebocoran cairan serebrospinal dan infeksi. Berdasarkan suatu penelitian retrospektif pada 306 pasien yang melihat komplikasi pascaoperasi pembedahan pasien dengan kraniosinostosis, mendapatkan bahwa salah satu komplikasi pascaoperasi adalah kebocoran cairan serebrospinal (2,7\%). Berdasarkan penelitian lainnya menyebutkan bahwa higroma subdural merupakan salah satu komplikasi pascaoperasi rekonstruksi kraniofasial. ${ }^{6-10}$

Pada kasus ini dilakukan pemanjangan ventilasi mekanik pascaoperasi hingga kondisi permasalahan metabolik telah teratasi. Pemanjangan ventilasi mekanik tersebut dilakukan karena durasi operasi yang panjang (19 jam) dengan posisi prone, adanya kondisi hidrosephalus preoperasi, perdarahan dan pergantian cairan intraoperasi yang masif. Hari ke-3 perawatan pascaoperasi dilakukan tindakan pemasangan VP-shunt karena terjadi kebocoran cairan serebrospinal dan berdasarkan CT-scan kepala terjadi kondisi memperberatnya hidrosephalus.

\section{Simpulan}

Penanganan perioperatif pasien dengan sindroma pfeiffer yang akan dilakukan prosedur operasi 
kraniofasial membutuhkan penanganan secara multidisiplin kelimuan. Berbagai permasalahan yang kompleks dapat terjadi pada pasien dengan sindroma pfeiffer, sehingga dibutuhkan pemahaman yang mendalam mengenai fisiologi, potensi permasalahan intraoperasi, resiko dan komplikasi pascaoperasi untuk mencapai hasil luaran yang baik.

\section{Daftar Pustaka}

1. Lee MY, Jeon GW, Jung JM, Sin JB. A case of pleiffer syndrome with c833_834GC $>$ TG (Cys278Leu) mutation in the FGFR2 gene. Korean J Pediatr. 2010;53(7): 774-7.

2. Vogels A, Fryns JP. Pleiffer syndrome. Orphanet Journal of Rare Dissease. 2006;1(19): 1-3.

3. Bajwa SJS, Haldar R. Craniosynostosis surgery-anaesthetic challanges and implications. Medical Journal of Dr.D.Y Patil University. 2015;8(3): 364-6.

4. Pearson A, Matava CT. Anaesthetic management for craniosynostosis repair in children. BJAEducation. 2016;16(12):410-6.

5. Nishimoto S, Oyama $T$, Nagashima $T$,
Osaki Y, Yoshimura Y, dkk. Lateral orbital expansion and gradual fronto-orbital advancement: an option to treat severe syndromic craniosynostosis. J Craniofac Surg. 2008; 19: 1622-7.

6. Stricker PA, Fiadjoe JE. Anesthesia for craniofacial surgery in infancy. Anesthesiology Clin. 2014;34:215-35.

7. Esparza J, Hinojosa J. Complications in the surgical treatment of craniosynostosis and craniofacial syndrome: apropos of 306 transcranial procedure. Childs Nerv Syst. 2008;24(12):1421-30.

8. Erten E, Cekmen N, Bilgin F, Orhan ME. Respiratory and cranial complications during anaesthesia in pfeiffer syndrome. Brain Disord Ther. 2015; 4(4):1-3.

9. Hockstein NG, McDonald-Mcginn D, Zackai E, Bartlett S, Huff DS, Jacobs IN. Tracheal anomalies in pfeiffer syndrome. Arch Otolaryngol Head Neck Surg. 2004; 130:1298-302.

10. Ganesh P, Nagarjuna M, Shetty S, Salins PC. Subdural hygroma after craniosynostosis surgery. J Craniofac Surg. 2015; 26(1):193-5. 